\title{
Theorizing the Diffusion of International Human Resource Practices: Towards an Integrated Conceptual Approach
}

\author{
Ifedapo Adeleye \\ Human Resources Department, Pan-African University \\ P.O. Box 73688, Victoria Island, Lagos, Nigeria \\ Tel: 234-1-774-0820Ｅ-mail: iadeleye@lbs.edu.ng
}

Received: March 7, 2011

Accepted: April 29, 2011 Published: December 1, 2011

doi:10.5539/ijbm.v6n12p254

URL: http://dx.doi.org/10.5539/ijbm.v6n12p254

\begin{abstract}
With the increasing globalization of the world economy and the rapid diffusion of international management practices, a vast literature has emerged on how and why some of these practices are adopted or rejected by firms. A central issue in this body of literature is whether firms' adoption of management practices is triggered by a need to improve corporate performance (rationalism) or necessitated by institutional factors and constraints (institutionalism). This review of rationalist and institutionalist conceptual approaches is particularly interesting given that in the (prescriptive) human resource management literature the rationalist presumption of strategic choice and managerial autonomy is usually taken for granted, a view institutionalist approaches tend to criticize for being overly rationalist and acontextual. In concluding, the paper agues that since organizations are faced with both rationalist and institutionalist pressures in their choice of human resource practices, there is a need for robust, integrated frameworks that incorporate this duality.
\end{abstract}

Keywords: International human resource practices, Institutional theory, Comparative institutionalism, New institutionalism, Rationalism, Institutional rational choice

\section{Introduction}

A whole host of studies have emerged exploring how and why ideas and practices are adopted by organizations and to what extent these processes are concerned with improving organizational performance. However,...little attention has been paid to the various theoretical positions, problems and possibilities evident in this literature.

Sturdy (2004: 155)

Given the emergence of several "innovative" or "new" international management practices and fads in recent years, and the tendency for these practices to diffuse rapidly across national borders, it is not surprising that a vast literature has emerged on how and why they are adopted by firms (see, for example, Leseure et al., 2004; Subramony, 2006). A central issue in this body of literature is whether firms' adoption of management practices is triggered by a need to improve corporate performance (rationalism) or necessitated by environmental /institutional pressures and constraints (institutionalism). The critical review of these contrasting conceptual approaches is the primary objective of this paper. The review is particularly interesting given that in the (prescriptive) Human Resource Management (HRM) literature the rationalist presumption of strategic choice and managerial autonomy is usually taken for granted, a view institutionalist approaches tend to criticize for being overly rationalist and acontextual. Our objective here is to gain a deeper understanding of these two theoretical perspectives, highlighting their usefulness and limitations in explaining the diffusion of international HRM practices.

This remainder of this paper is organized into four main sections. In section 2, the economic approach and the alignment approach, two rationalist conceptual approaches, are reviewed. This is followed by a critique of two institutionalist conceptual approaches: comparative institutionalism and new institutionalism, in section 3. Drawing from our analysis of the relative strengths and weaknesses of these conceptual approaches in theorizing the diffusion of management practices in the preceding two sections, in the fourth section an argument is made for an integrated conceptual approach that incorporates the strengths of both rationalism and institutionalism. We conclude, in section 5 , by proposing the institutional rational choice approach, stating its usefulness as a framework for theorising the diffusion of international HR practices. 


\section{Rationalist Approaches}

From the rationalist perspective, organizations' choice of HRM practices is essentially determined by "technically efficiency" considerations such as their economic utility and alignment with the firm's business strategy (Subramony, 2006). The notion of rationality is implicitly assumed in the strategic HRM literature, where there have been several attempts to provide linkages between people management practices and organizational strategy (Wright, McMahan and McWilliams, 1994; Kamoche, 1996).

Many of these studies draw extensively from the resource-based view of the firm in the strategic management literature. According to the resource-based view, a firm can achieve a sustainable competitive advantage from its internal resources if these resources are valuable, rare, inimitable, and non-substitutable (Barney, 1991. Many researchers have argued that human resources (potentially) meet these four criteria (Snell et al., 1996). Therefore to gain a competitive advantage through people, firms should seek to integrate their HR competencies (the skills, abilities and talents of their employees) into unique organizational capabilities (Kamoche, 1996). Kamoche's (2000) "processual, strategic model of HRM for Africa", for instance, provides a prescriptive framework for aligning people management practices and competencies with a firm's business strategy. In a similar vein, Taylor et al. (1996) have developed a resource-based model for international HRM. They assert that MNCs can enhance their international competitiveness by transferring their organizational competencies across their global operations. However, these resource-based models have been criticized for being unitarist and internally-focused (Khan and Ackers, 2004). The contention here is that the emphasis on organizational differentiation or idiosyncrasy is impracticable since all firms need some degree of uniformity to meet the standard (sectoral) expectations of their customers, employees, critical resource providers, regulators and other key stakeholders (Boxall and Purcell, 2003).

While it is quite clear that efficiency is the key factor in the determination of HRM practices for rational choice theorists, they have several competing explanations and criteria for arriving at what actually constitutes an efficient choice. There are at least two broad schools of thought: the economic approach and the alignment approach (Subramony, 2006). The economic approach defines efficient choice in terms of the economic value or impact of a practice on corporate financial performance. In the strategic HRM literature, this is associated with the universalistic or "best practice" approach. The alignment approach emphasizes the need for a "fit" between HRM practices on one hand and a firm's business strategy and other contingent factors on the other hand. In the strategic HRM literature, this is often referred to as the contingency or "best fit" approach.

From the economic approach, HRM practices are adopted on the basis of their contribution to the firm's financial performance in terms of either revenue generation or cost reduction (Subramony, 2006). This view is reflected in the strategic HRM literature by the several studies that seek to establish a causal link between HRM practices and corporate financial performance (see for example, Huselid, 1995; Becker and Gerhart, 1996; Wood and de Menezes, 1998; Guest et al., 2003). Further, there have been several prescriptive lists of "high performance management", "high performance work systems", "human capital enhancing HR systems", "high commitment management" and "high involvement management" practices that purportedly improve organizational performance when implemented together (see for example, Pfeffer 1994, 1998). Such practices typically include team-working, functional flexibility, employee empowerment, extensive training and employee development, performance appraisal, counselling, and performance-based pay (Heery and Noon, 2001).

The limitations of this "best practice" approach are quite obvious. By claiming that certain HRM practices are universally applicable, it ignores the critical role of the organization-specific and other contingency factors in shaping HRM practices (Marchington and Grugulis, 2000). In other words, many of these best practices (such as high levels of pay, training and employment security) may not be cost-effective or viable across all sectors or, indeed, across all the segments of the workforce in a firm (Boxall and Purcell, 2000). Moreover, the implicit assumption of this approach - that the determination of HRM practices is solely based on rational and strategic choices made by managers - underestimates the crucial role played by social and political actors such as employees, labour unions and regulatory bodies.

The alignment approach is possibly a more appropriate rational choice explanation as it acknowledges the importance of context and firm-specific factors in shaping organizations' HRM practices. There are, however, diverse viewpoints as to which contingency factors HRM practices should seek to match. The most widely accepted one, Schuler and Jackson (1987), maintains that HRM practices should reinforce the behavioural implications of firms' competitive strategies (innovation, quality enhancement, or cost reduction). Keltner and Finegold's (1996) normative framework posits that banks should adopt a relationship orientation (innovation or differentiation strategy) for high-end retail customers and small- and medium-sized enterprises and a transaction orientation (cost leadership strategy) for other less profitable retail customers. They then propose that banks adopting the former strategy should invest heavily in developing their human resource competencies while those adopting the latter approach should focus on leveraging on the more cost-effective information technology 
competencies. Also, Weinstein and Kochan (1995: 24) posit there available evidence supports the view that new HRM practices are more widely adopted in greenfield sites than in existing facilities, and in larger firms than in small and medium-sized enterprises. Supporting this view, Sett's (2004) study in the South Asian context reports higher rate of adoption of HRM practices by relatively newer firms, most of which focus on high-value added segments of the market. The point that mature firms may find it more difficult to introduce new HR practices is based on the fact that many of them have firmly embedded practices and they are often resistant to change as a result of "system inertia" (Ichniowski et al., 2000). For the same reason, in the case of subsidiaries of multinational corporations, the parent company's mode of market entry (greenfield development versus brownfield acquisition) may impact on the their ability to introduce new HRM practices (Oliver and Wilkinson, 1992). Marchington (1990) also posits that organizations' employee relations practices are shaped by competitive pressures and changes in the product market, a view supported by several empirical studies (Barry and Nienheieser, 2010; Oxenbridge et al., 2010). However, like the economic approach, the alignment approach has been criticized for overstating the degree of managerial autonomy or strategic choice available to firms while underestimating the influence of institutional pressures.

In concluding this section, rational choice explanations have been criticized for been acontextual and an oversimplification of the complexity of the decision-making process in organizations (John, 1998). In particular, this approach has been criticized for overstating the degree of managerial autonomy while underestimating the influence of institutional pressures. Gooderham et al. (1999), for instance, have argued that national institutional embeddedness plays a much more critical role in shaping HRM practices than rational or strategic factors. They therefore maintain that the role of institutions must be accentuated in studies of employment practices.

\section{Institutionalist Approaches}

Institutionalist approaches emphasize the critical role of societal rules and norms, as well as political and economic structures, in shaping human resource practices. Two broad institutionalist schools of thought can be identified in the literature: comparative institutionalism and the new institutionalism (Almond and Ferner, 2006). Despite many variants of terminology - including "varieties of capitalism", "national business systems" and "societal effects" - the central thesis of comparative institutionalism is that organizations' management practices are largely influenced by national-level structural and regulatory arrangements (Schief, 2010; Hall and Soskice, 2001; Lane, 1989; Whitley, 1999). From the new institutionalist perspective, organizations' HRM practices are shaped by coercive, normative and cognitive pressures exerted by competitors and other social actors (DiMaggio and Powell, 1983; Pfeffer and Salancik, 1978).

Although these two approaches share the viewpoint that "institutions matter", they differ considerably in terms of their conceptualization of institutions, units of analysis and mechanisms of adaptation (Tempel and Walgenbach, 2007). In terms of their conceptualization of institutions, while comparative institutionalists focus mainly on regulatory and structural institutions (such as financial, education and judicial systems), new institutionalists focus on regulatory and structural, as well as normative and cognitive institutions. Their unit of analysis also differs. While comparative institutionalists are primarily concerned with understanding the "societal effect" created by national-level institutions, new institutionalists focus on "organizational fields". These fields could be at the sectoral, national or even international level. The two approaches also differ in terms of mechanisms of adaptation. Comparative institutionalists maintain that firms are constrained to act in similar ways by national institutional arrangements, and that their adaptation to the environment is motivated by "economic" considerations. This is based on their view that economic action is embedded within local governance and institutional arrangements (Hollingsworth et al., 1994). In contrast, new institutionalists assert that organizations in a "field" behave in similar ways due to similar coercive, mimetic and normative pressures they face, and that adaptation is primarily for legitimacy (and not economic) reasons (Almond and Ferner, 2006). Below, an extensive discussion of the two institutionalist approaches is provided.

\subsection{Comparative Institutionalist Perspective}

Comparative institutionalists emphasize the importance of examining organizations in relation to the social institutional environment in which they are nationally embedded (Lane, 2000; Maurice et al., 1980; Hollingsworth and Boyer, 1997; Warner, 2000a; Sorge et al., 1983; Ebbinghaus and Visser, 1999; Chow, 2004). This institutional embeddedness comprises of the financial system, educational system, business system and the system of research or innovation (Hollingsworth, 1997). According to this perspective, therefore, all organizations existing within the same national border or system will adopt similar HRM practices since they are constrained by similar social and institutional pressures. Three theses: path dependence, institutional complementarity and institutional hierarchy epitomize the comparative institutionalist viewpoint.

The path dependence thesis holds that modes of economic governance and management are nationally-specific and therefore not easily amenable to imitation or replication in other national contexts (Hollingsworth, 1997). 
Therefore, even when national institutional arrangements face pressures for convergence as a result of increasing globalization, "these pressures will lead to modification and change of societal institutions, but the particular form of the response will reflect each country's societal logic" (Rubery and Grimshaw, 2003:39). Path dependence has been used by several scholars to explain the relative stability of institutions and management systems. For example, Warner's (2004:617) study of the evolution of HRM systems in China maintains that although there has been a major change from the Soviet-style personnel management approach towards Western-style HRM systems, the newer system still exhibits "strong Chinese characteristics". This concept is quite useful as it highlights the salient role of institutional continuities in shaping managerial choices (Muller-Camen et al., 2011).

The concept of complementary institutions is based on the notion that institutions (e.g. financial, educational and business) are highly dependent on one another, and that the coherence and strength of the entire national institutional structure depends on the interaction of these various institutions (Amable, 2000; Hall and Soskice, 2001). This implies that when management practices diffuse from one country or institutional context to another, the practices would interact differently with the institutional arrangements in the adopting country and therefore necessitate the adaptation of such "imported" practices (Campbell, 2004). For example, Vitols (2004) claims that in Germany where there has been increasing adoption of Anglo-Saxon, "shareholder-value" oriented practices, many firms have made considerable adaptations - a "German version" - to suit the local environment where strong stakeholder rights and involvement exist.

Related to the concept of institutional complementarities is the notion of a hierarchy among institutions. Institutional hierarchy means that the various institutional forms do not have equal weight in the overall national institutional structure, as one or a few strong institutional forms tend to impose their logic on the others (Amable, 2000; Boyer, 2000). For example, Boyer (2000) argues that in the 1990s, the financial system seemed to dominate other institutional forms.

A number of institutionalist authors have attempted to group various national institutional structures and arrangements into broad categories based on criteria such as the relative importance of market mechanisms in the governance of economic relationships and the hierarchy of networks formed by the major economic actors. For example, Hall and Soskice (2001) have contrasted "liberal market economies" such as the United Kingdom and the United States with "co-ordinated market economies" such as Japan and Germany. In the former group, economic actors rely more on market mechanisms and relations while in the latter corporatist-type networks and government interventions are predominant.

This variation in business systems has been used to explain differences in national HRM systems (Chow, 2004; Quack et al., 1995; Gooderham et al., 1999). Quack et al. (1995), for example, have argued that differences in the recruitment and training practices of British, French and German banks can be attributed to variations in their national business systems. They assert that in "corporatist" France and Germany, training provision was more effective and there was a bigger pool of skilled workers as firms co-operated in funding sectoral training programmes. In contrast, in "individualistic" Britain with its weak public training systems, training was less effective and the availability of a pool of highly skilled workers was limited, with many "free-riding" firms depending on the flexible external labour market for trained and qualified employees. In a similar vein, Farndale et al. (2008), in their extensive survey of HRM practices of multinational firms in four European countries: UK, Germany, the Netherlands and Sweden, conclude that the differences in HRM practices between foreign- and locally-owned MNCs, as well as between MNCs and local organizations can be attributed to the firms' embeddedness in their home country environment. Also, Schief's (2010) study of flexibility patterns in local and multination companies across five European countries concludes that the national institutional framework is still a dominant factor in the organisation of labour and employment, even within MNCs.

Some institutionalist authors have taken this a step further by proposing that the impact of national business systems on the creation of organizational knowledge and competencies plays a critical role in the determination of industry-specific competitiveness. For example, Haake (2002) asserts that co-ordinated market economies would have a competitive advantage in industries with a high firm-specificity of knowledge (that is, industries in which work organization and technologies are peculiar to firms, and therefore not easily imitated by competitors). Conversely, liberal market economies would have a competitive advantage in industries with a low firm-specificity of knowledge. Haake argues that this explains why "co-ordinated" Japan is highly competitive in consumer electronics, machine tools or luxury cars where "liberal" United States is lagging behind, and relatively weak in industries such as consulting, software, advertising, banking and biotechnology where the United States is strong. Casper, Lehrer and Soskice's (1999) comparative analysis of high-technology sectors in the United States and Germany corroborates this view. They argue that the availability of large amounts of venture capital to high-risk start-up entrepreneurs and the close links and collaborations between university scientists and large innovative companies in the United States largely accounts for the success of bio-tech and software firms there. In Germany, however, where venture capital and university-industry collaboration are not 
as well developed owing to their national institutional framework, the high-technology sector is relatively unsuccessful, whereas the less-risky, mid-technology sector thrives.

Comparative institutionalism, however, has its weaknesses and limitations. These include: static descriptions that tend to overestimate the durability of institutional values and arrangements; a deterministic view that treats organizations as passive reactors to their institutional environment; and an inherent assumption that national institutions and systems are homogeneous. In addition, comparative institutionalism can be criticized on the grounds that it focuses narrowly on regulative and structural institutions while ignoring the key cognitive and normative institutions.

The first weakness, the static description of national institutional arrangements, arises because of the tendency to focus solely on explaining stability and continuity of national systems while ignoring the significant changes that are taking place across the globe (Deeg and Jackson, 2007). In particular, the impact of globalization and increased international competitive pressures on both national systems and individual firms is underestimated (Mueller, 1994). Indeed, diverse evidence lends credence to the notion that national institutional systems are amenable to change (see, for example, Djelic and Quack, 2003). The widely documented "transformation" of Japanese management systems is a very good example. Several studies confirm that lifetime employment, seniority-based wages and promotion, and enterprise unionism - the so-called pillars of Japanese management - are facing considerable changes as a result of the economic downturn in that country in the mid-to-late 1990s and increased global competitive pressures (see Dalton and Benson, 2002; Lincoln and Nakata, 1997; Morishima, 2003; Kuruvilla and Erickson, 2002; Morris, Hassard and McCann, 2006, Barry and Nienheieser, 2010). Further, authors such as Muller-Camen et al. (2011) have argued that the concept of path dependence tends to underestimate the active ways organisations seek to explore and exploit options within the constraints of national institutional arrangements.

In fairness, however, some more recent comparative institutional theorists provide more dynamic explanations that emphasize institutional change rather than stability and self-reinforcing path-dependencies (for example, Streeck and Thelen, 2005; Thelen, 2004; Streeck, 1997; Campbell, 2004). They acknowledge the erosion of institutional arrangements over time as a pragmatic response to dynamic global environmental pressures for convergence. Streeck (1997), for instance, maintains that under increasing pressure from "shareholder capitalism" associated with liberal market economies, the idiosyncratic labour and corporate governance institutions characteristic of co-ordinated market economies such as Germany are bound to evolve. Streeck and Thelen (2005) also report that "incremental change" in the co-ordinated market economies of Denmark, Germany and Japan have necessitated a "gradual transformation" of labour market and welfare, industrial relations, vocational training, and corporate governance systems in these countries. However, these explanations are deeply embedded in the comparative institutionalist tradition of path dependence, emphasizing evolutionary (as opposed to revolutionary) change resulting from various processes of "recombining", "translating" or "layering" new practices with existing ones (Streeck and Thelen,2005; Campbell, 2004).

The assumption of a homogeneous or dominant national business and employment system is yet another weakness of comparative institutionalism (Deeg and Jackson, 2007; McSweeney et al., 2008). Just like cultural relativism, it trades on recognisable, rather stereotypical, characteristics of national institutional systems. The characterization of Japan, France and Germany as co-ordinated market or communitarian business systems and Britain and United States as liberal or individualistic business systems, for example, is widespread in the literature (for example, Whitley, 1999; Haake, 2002). However, some scholars have argued that the existence of "institutional partitions" within nations implies that there may be considerable variation within them (Crouch, 2005; Deeg and Jackson, 2007; Allen, 2004). As a result, they argue, many countries do not neatly fit the national models that are so often used to describe them. Deeg and Jackson (2007: 155) coined the expression: "models within models" to describe this apparent heterogeneity within national models. Supporting this view of "models within models", Sorge (2005) posits that in Germany, which is widely regarded as a homogeneous, co-ordinated market economy, there are considerable differences in the organization of political economic activities between the southern and northern regions as a result of distinctive "meta-traditions" or historical legacies. Also, Katz and Darbishire's (2000) study of employment practices in the automobile and telecommunications industries across seven industrialised countries (Australia, Britain, Germany, Italy, Japan, Sweden, and the United States) indicates that intra-national variation in employment systems is rife. Their findings suggest that there are similarities in the employment practices adopted by firms in the same sector in these seven countries. This indicates that in view of the globalization of product markets, it may be more appropriate to speak of the "sectoral effect" or sectoral models rather than the "societal effect" or national models. What all these studies demonstrate is that the comparative institutionalist conception of a single national model of business and employment may be inappropriate.

Beyond the issue of institutional diversity, the extensive institutional changes taking place across the globe also question the continued relevance of the notion of homogeneous business systems. As mentioned above, many of 
the so-called co-ordinated economies are under enormous pressure and are indeed embarking on more liberal market-oriented institutional reforms. It is not surprising therefore that some authors maintain that the national or societal effect is increasingly diminishing, as organizations and states conform to global organizational structures and employment systems (Mueller, 1994). As Djelic and Quack (2003: 317) succinctly put it, "globalization is disrupting the systemic stability and relative autonomy of national spaces. It is pushing along common logics that coexist, compete, hybridize with or even replace incumbent national institutions".

However, this is not to suggest that national institutional arrangements do not matter at all, or that comparative institutionalism does not offer any useful insights in the analysis of HR practices and systems. In the context of global HRM, for example, one very useful insight is the extent to which institutional arrangements in the home and host country impact on the HRM practices of multinational corporations (MNCs) and their subsidiaries. Not surprisingly, perhaps, the literature in this area is polarized.

On one hand, there is the view that MNCs take the key features of their home country's institutional context when expanding abroad, such as strategy, structure and HRM practices (Ferner and Quintanilla, 1998) and modes of control (Harzing and Sorge, 2003). According to this view, the progressive globalization of markets and the rapid diffusion of neo-liberalism have substantially reduced national differences, cross-national transfers of management practices are viable (Mueller, 1994). Under this scenario, the focus of firms is on migrating "global best practices" from the head office to subsidiary units through global benchmarking mechanisms and the deployment of expatriate managers who act as agents of diffusion (Ferner and Quintanilla, 1998; Westney, 1993). Here, the parent company's orientation towards its subsidiaries in terms of power and decision-making plays a major role in shaping the nature and extent of isomorphism. Two contrasting orientations are discernible: ethnocentrism and polycentrism (Perlmutter, 1969). In the ethnocentric orientation, where power and decision-making are concentrated at the headquarters, subsidiaries are expected to conform to the parent company's HRM systems. In contrast, in the polycentric approach subsidiaries retain substantial power and decision-making and therefore have more latitude to choose whatever HRM practices they deem appropriate to the local environment.

There is also the view that even if MNCs have a polycentric orientation towards their subsidiaries and plan to transfer practices to the host country, it may be impossible to do so if conditions there are not conducive or "receptive" in the host country. Hence, it is simplistic to assume - even in a globalized era - that there will be no local resistance to international HRM practices (Rowley and Bae, 2002: 2).

\section{Ideas concerning globalization's impacts on human resource management rest on two presumptions. Not only is it a question of globalization's power, but there is also the commensurate weakness and receptiveness of the terrain it flows over.}

Indeed there is empirical evidence to support this view. Parry et al. (2008), in their study of HRM practices in American MNCs (known for their preference for exporting their home country practices when expanding abroad), report that the ability of these corporations to successfully transfer their HRM practices is highly dependent on how liberal or tightly regulated the host countries are. Hence, in spite of ethnocentric pressures for cross-border diffusion and the power and influence of some multinational corporations, they may be prevented from importing their HRM practices by stringent local customs and employment regulations.

However, it can also be argued that MNCs, with their huge financial and political capital, may be able to transfer their home practices easily, even in the face of unfavourable host environments. Indeed, some scholars have argued that MNCs play a crucial role in the evolution of both their home and host country business systems (see, for example, Ferner and Quintanilla, 1998).This may be a credible assertion, given their increasing reach and power. The top 1,000 MNCs are responsible for 80 per cent of the world's industrial output and 53 of the 100 largest economic entities in the world are MNCs (Chanda, 2003). With this enormous economic bargaining power, they have been able to successfully lobby governments to change labour laws and regulations in their favour (Rubery and Grimshaw, 2003). Indeed, there is widespread evidence from studies in countries such as India, China and Taiwan that MNCs have been able to successfully implement "institutionally contested" practices in their overseas subsidiaries (see, for example, Som, 2007; Cooke, 2005; Gamble, 2003; Chen et al., 2005).

In concluding therefore, it is important to maintain a balance in the analysis of cross-border HRM transfers: between the willingness and ability of the parent company to migrate HRM practices to their subsidiaries abroad and the receptiveness of local customs and employment systems. Given the power and influence of MNCs, it is easy and convenient to exaggerate the former at the expense of the latter, a pitfall researchers must avoid.

\subsection{New Institutionalist Perspective}

The central thesis of new institutionalism is that organizations operating in the same institutional environment will behave in similar ways (i.e. isomorphism) since they are subject to similar regulatory, normative, cognitive and 
resource constraints (DiMaggio and Powell, 1983; Pfeffer and Salancik, 1978). This implies that firms' decision to adopt certain people management practices is largely influenced by their desire to acquire and maintain legitimacy with key resource providers, competitors and other social actors, rather than, or even regardless of, any technical or economic efficiency considerations (Whittington, 1992). By extending their conceptualization of institutions beyond regulatory and structural arrangements to cover normative and cognitive factors, the new institutionalist approach offers a broader and more robust framework than comparative institutionalism.

DiMaggio and Powell (1983) have identified three forces through which isomorphism occurs in institutional environments. First, coercive isomorphism which emanates from pressures from regulatory authorities and other key resource providers; Second, mimetic isomorphism which arises from responses to ambiguous performance criteria and uncertain technologies; Third, normative isomorphism which stems from values, ideas and practices advocated by educational institutions, management consultancies and professional associations. McKinley et al.(1995) use the terms "constraining", "cloning", and "learning" to describe these three forces.

Coercive isomorphism stems from formal and informal pressures exerted on organizations by regulatory authorities and other firms which they depend on for key resources. Thus, isomorphic changes may be triggered by the need to comply with government advisory initiatives or regulations (Leseure et al., 2004), shifts in business ideology and customs (McKinley et al., 1995), pressures from key clients (Swart et al., 2002) and international pressures for coercion from global governance institutions (Henisz et al., 2004).

McKinley et al., for example, have attributed the pervasiveness of organizational downsizing in large companies in the United States to changes in the ideological perception of downsizing as a result of the prevalent preoccupation with maximizing shareholder value. Downsizing, which was previously associated with economic decline, is now linked with cost efficiency, competitiveness, and financial prudence as a result of increasing emphasis on creating quick, short-term value for shareholders and investors (Lazonick, 1993). In this way, organizations are obligated to downsize their workforce as they are "rewarded" for doing so with share price increases in the financial markets. Coercive pressures may also be exerted by head office of multinational corporations on their overseas subsidiaries through global benchmarking of practices and the deployment of expatriate managers to "export" firm-specific practices or systems, as earlier mentioned.

Labour unions are also widely regarded as a facilitating or constraining force to the diffusion of (innovative or new) employment practices. Katz and Darbishire (2000), for instance, posit that the declining power of unions across the globe - which has given managers a higher degree of autonomy - may have contributed to global convergence of employment systems. In a similar vein, Ramaswamy and Schiphorst (2000) and Som (2007) also assert that in India where unions are relatively powerful, they hinder the adoption of innovative HRM practices in many organizations. This is often as a result of the lengthy negotiation and consultation process managers have to undertake to get union approval or support of such practices.

The cloning forces of mimetic isomorphism are triggered by organizations' desire to be seen as "progressive" by their competitors, shareholders and other social actors (Abrahamson, 1991). This usually arises from a need to acquire and legitimacy from important stakeholders in the wake of uncertain or ambiguous performance standards or technologies. Organizational identity plays a critical role in the mimetic process, as it is stronger among firms that consider themselves as peers. Li et al.'s, (2007) study of the diffusion of wholly owned foreign subsidiary mode of market entry in China corroborates this view. Their findings suggest that organizations sharing a common identity in terms of country of origin and industry segment exert stronger mimetic pressures on each other in their choice of market entry strategies. In a similar vein, Barreto and Baden-Fuller's (2006) study of bank branching decisions in Portugal found that location decisions were largely driven by pressures to conform to decisions of other banks in their "legitimacy-based reference groups". Hence, they decided to open branches not only in the attractive locations that their peers had chosen, but also in relatively unattractive and unprofitable locations.

New or innovative HRM practices are particularly susceptible to mimetic pressures since the practices are usually considered modern and fashionable; further, there is a lack of (compelling) evidence that these practices actually "work". In the face of uncertainty or ambiguity, organizations often just bow to mimetic pressures to conform, relegating or even ignoring performance considerations. Returning to the concept of legitimacy-based reference groups, an interesting issue that arises is whether subsidiaries of multinationals, as members of a global reference group, will imitate HR practices of their parent company/home country or whether they will conform to prevailing local practices. There is a strong argument that given their enormous size, reputation, reach and power, MNCs have the potential to lead the way in the adoption of new or "best" HR practices (Bjorkman, 2002; Rubery and Grimshaw, 2003; Ietto-Gillies, 2002; Venkata Ratnam, 1998). While this suggests that locally-owned firms will tend to mimic the practices of their foreign-owned counterparts, available evidence on some developing countries report that many of them, particularly family-owned ones, tend to be slower in adopting (new) HRM practices due to their conservative and paternalistic management style (Arias, 1993; 
Lawler et al., 1989; Som, 2007).

The third source of institutional isomorphism stems from normative pressures exerted on organizations by influential "learning" institutions such as educational and professional establishments, management consultancies, and professional associations (Scott, 2001). Managers often look up to scholars or "management gurus" in business schools to provide new insights and best practices. In this way, they can be regarded as "transmission belts" through which knowledge generated from interactions with managers and academicians is disseminated to students on MBA and other educational programmes (Howorth et al., 2002 and Wright and Kitay, 2004). Management consultants, who have been described as "experts and fashion setters of the business community" (Berglund and Werr, 2000: 633), also play a crucial role in the diffusion of management practices (Mamman, 2002; Som, 2007).

While there is no doubt that the new institutionalism has been useful in highlighting the critical role of institutions in constraining or facilitating the adoption of (new) management practices, some fundamental weaknesses are inherent in some of its propositions. Just like comparative institutionalists, "new institutionalists have tended to neglect the issues of interest, agency, conflict and change in their arguments" (Tempel, 2001: 41). In an attempt to counter rationalist claims of strategic behaviour and their preoccupation with efficiency considerations, for example, Scott's (1995) analysis of the "cognitive pillar of institutions" emphasizes the inability of firms to transcend institutionally established norms or modes of cognition. The underlying assumption here is that once "established", institutional arrangements or practices become taken-for-granted and are neither contested nor contestable by any institutional actor, irrespective of their interests and relative power. However, as Edwards et al. (2007: 203) have observed, "there is a need to see institutionalization as a contested process in which groups have different interests and varying power resources through which to pursue them". Several other scholars support such a view, emphasizing the dynamic and multi-directional relationship between organizations and institutions (Looise et al., 1998; Ferner and Quintanilla, 1998; Allen, 2004). For example, Looise et al.'s, (1998) study of the employment system in the Netherlands indicates that the system has evolved largely in response to pressures from organizations for more flexibility in employment management. The resultant changes in the country's labour regulations, have in turn (re)shaped the HRM practices adopted by firms. There is also widespread evidence that some MNCs have been able to successfully implement "institutionally contested" practices in their overseas subsidiaries (see, for example, Som, 2007; Cooke, 2005; Gamble, 2003; Chen et al., 2005). In India, for example, Venkata Ratnam (1998) and Som (2007) posit that MNC subsidiaries introduce innovative HRM practices that conflict with the traditional pluralist and collectivist approach to employment relations. Hence, the tendency of new institutionalists to underestimate the crucial role of rational choice and independent action in the adoption process is unacceptable.

Another discernible weakness of new institutionalism is the "presumption of the dichotomy or necessary antagonism of technical and institutional environments" (see Orru et al., 1991:362). This dichotomy is evident in the narrow focus of new institutionalist studies to organizations that are particularly vulnerable to institutional pressures, such as hospitals, educational establishments and public sector agencies (see DiMaggio and Powell, 1991). Orru et al. argue that institutionalist explanations should also be applied to "technical" environments (i.e. business organizations) since firms in this group are equally subject to institutional pressures. However, there have since been some attempts to extend new institutionalist explanations to technical environments and markets (see, for example, Rosenzweig and Nohria, 1994; Kostova and Roth, 2002). Furthermore, Orru et al. maintain that the dichotomy between institutional isomorphism and competitive isomorphism is not justifiable since national institutional arrangements are inherently designed to enhance market relations and organizational efficiency.

The review of the rationalist and institutionalist conceptual approaches illustrates the richness and explanatory power of both perspectives. However, it also shows that the two perspectives have considerable weaknesses which limit their usefulness and relevance in theorizing the diffusion of management practices. It is also clear from this review that the two contrasting perspectives can "learn" from each other. Hence, following other researchers like Edwards et al. (2007), an argument is made for an integration or fusion of both theoretical approaches, as this provides a richer and fuller description of the diffusion process. Such an integrated approach is particularly useful since organizations often face the dual pressures to "perform and conform" (Barreto and Baden-Fuller, 2006: 1559; Hunter, 1995: 23), as indicated above.

\section{Towards an Integrated Conceptual Approach}

Choices of particular HRM practices may reflect organizational power and politics and institutional norms of best practice as much as they reflect strategic goals or performance imperatives.

Hunter (1995: 23)

There is no reason any organization might not be as subject to competitive factors as to 


\section{institutional factors.}

Orru et al. (1991: 362)

In the two previous sections, the rationalist and institutionalist conceptual approaches to analyzing the adoption of management practices were reviewed, with the conclusion that an integrated perspective that draws from both frameworks produces a richer and more nuanced analysis of the diffusion process. We argued that such an approach is particularly useful for theorizing the diffusion of HR practices, which are known to be susceptible to both rational/strategic and institutional/normative pressures, as the quote above indicates.

Indeed, there have been some attempts to narrow the gap between the apparently diametrically opposed conceptual approaches, with the development of "softer" and more "sophisticated" theories on both sides. On the one hand, the notion that organizations' practices are solely determined by legitimacy considerations has been revised by some institutional scholars (see Orru et al., 1991). On the other hand, the role of institutional factors in constraining choices available to firms has been accentuated by some rationalist explanations (see Schmitt and Sadowski, 2003). Below, a review of some of these attempts to narrow the gap between the two contrasting approaches is discussed.

Orru et al.'s (1991) contestation of the dichotomy between technical and institutional environments can be regarded as an attempt to bridge the gap between rationalist and institutionalist explanations. In this empirical study of the behaviour of private firms in South Korea, Taiwan and Japan, it was found that businesses in each of the countries "operate according to different institutional principles and exhibit dissimilar organizational and inter-organizational structures that manifest those principles" (pp 363). Further, they posit that the institutional principles that shape organizational behaviour in these countries were designed to, and indeed enhance the competitiveness of business organizations. They therefore conclude that the distinction between market and institutional forces is unnecessary. This reasoning appears logical given that organizations are often involved formally and informally - in shaping societal institutions (Looise et al., 1998). However, it is simplistic to presume that governments and other social institutions would always act in the interest of capital; there is a real possibility of a "disconnect" between state regulations and social norms on one hand, and the dynamic business environment on the other, as a result of institutional inertia.

Schmitt and Sadowski's (2003) study of the cross-national transfer of employment practices in Anglo-Saxon MNCs in Germany has also attempted to incorporate institutional factors into their rationalist framework. Using "fiscal federalism" as a theoretical analogy, they argue that the multinational firm can be likened to a federation, with the parent company as the federal, central authority and the subsidiaries as the federating states or regions. In this federal structure, "rationalistic cost-minimization" is the decisive factor in whether the provision of public goods is centralized or decentralized. Where the costs associated with centralization (for example, the costs due to frustration of preferences and costs of violating external regulations and norms) are high, the provision of public goods is decentralized, and vice-versa. On the other hand, when the decentralization costs (for example, forgone benefits of economies of scale and costs of differentiation) are high, the provision of public goods is centralized, and vice-versa. Applying this concept to the cross-national transfer of HRM practices, they report that for HRM practices (such as variable pay, employee ownership and vocational training) where decentralization costs are high owing in part to the need for global consistency, the Anglo-Saxon subsidiaries adopted their parent company practices. In contrast, in the industrial relations area where costs of centralization are high, the prevailing host country practices were adopted. Here, decentralization is driven by the need to maintain legitimacy with employees and the local environment. This, they argue, explains why the British and American firms in their study decided to set up a works council, join an employers' association, and recognize multi-employer collective agreements even though they are not legally obliged to do so, or (traditionally) favourably disposed to such arrangements. In sum, Schmitt and Sadowski's analysis demonstrates that while firms are primarily driven by market and efficiency considerations, the high costs of non-compliance to institutional norms often compels them to be sensitive to their environment.

An extension of rational choice theory, institutional rational choice approach is another attempt to bring the salient role of institutions into rationalist explanations:

Rational choice attempts to explain how and why policy options are ultimately selected. Institutional rational choice theory takes this process further by recognizing that decision makers operate within their institutional contexts, which in turn affect the choices made.

Susskind et al. (2001: 97)

Harris (2008), for example, argues that the differences in admissibility of novel scientific evidence in judicial policymaking across various jurisdictions in the United States is largely influenced by prevailing institutionalized norms and standards in these regions; the decision of judges is ultimately constrained by the prevailing political wisdom and legal expectations in their region. In this regard, institutional rational choice 
approach can be regarded as a "softer" variant of rationalist theory since it predicts that institutionally accepted norms and standards alter the "rational" behaviour of self-interested individuals or organizations (Heck, 2004). However, there is also a strong emphasis on strategic behaviour and managerial autonomy in the institutional rational approach (Ostrom, 1999), thus, avoiding the problem of determinism associated with institutionalist approaches. This notion of strategic behaviour and autonomy is evident in Willman et al.'s (2006) "transaction cost approach" to theorizing the adoption of employee voice in Britain. They argue that given the voluntarism that characterized the British industrial relations terrain in the 1980s and 1990s, "whether an employer adopts a voice regime turns on employers" perceptions of the net benefits of worker voice to the firm" (pp 283). They however posit that changes in institutional rules triggered by the European Union Directive on Information and Consultation of Employees may alter the (rationalist) costs and benefits of adopting employee voice schemes, and ultimately employers' decisions.

This emphasis on strategic behaviour is particularly useful in countries characterized by increasing neo-liberalization and a regime that is not constricted by any "powerful" labour market institutions. In such environments, there is the lack of political will and the weak institutional capacity of government agencies to undertake supervisory and law enforcement responsibilities, even in such basic areas as: minimum wage operation, age limits on employment, union organizational rights, restrictions on working hours and employment protection (see, for example, Wood and Brewster, 2007; McCann and Schwartz, 2006). Apart from the increasing weakness of employment systems in many countries, the decline in the power and influence of labour unions has contributed to a high degree of managerial autonomy, "[providing] wide scope for managerial innovation in employment and labour strategies" (Rubery and Wilkinson, 1994: 11).

\section{Conclusion}

In sum, the core argument is that given the fact that organizations face both rationalist and institutionalist pressures in their choice of HRM practices, there is a need for robust, integrated frameworks that incorporate this duality. Hence, we proposed the Institutional Rational Choice conceptual approach. An emphasis on strategic behaviour is at the core of this approach, a rejection of the deterministic view of institutional theoreists that organizations are "captives" or passive reactors to their institutional environment. Although this essentially is a variant of rational choice theory - given the emphasis on managerial autonomy and strategic behaviour - it is indeed distinct from it. The IRC approach acknowledges and stresses the point that the range of indeterminacy organizations have is not infinite, but bounded by the institutional embeddedness of firms. In other words, the institutional constraints imposed by actors and institutions such as parent company policies, trade unions and regulatory systems really matter as they affect and alter the internal incentives confronting organizations in the pursuit of their "rational", goal-oriented behaviour (Ostrom, 1999).

The IRC approach is also distinct from rationalist-oriented institutional theories, such as the choice-withinconstraints new institutionalism (Ingram and Clay, 2000). While it may appear that the difference between them is only one of emphasis, there is a fundamental distinction. Institutional rational choice theory is first and foremost a theory of rational choice and individuals' behaviour is assumed to be directed toward pursuing and maximizing their self-interest. This is in contrast to Ingram and Clay's emphasis on "institutional forms", and how these constrain the behaviour of organizations in the pursuit of their interests. In sum, while this conceptual framework emphasizes constraints-within-choices, theirs emphasizes choices-within-contraints. The Institutional Rational Choice conceptual approach is particularly useful for theorizing in contexts where there is a reasonably high level of managerial autonomy and coercive pressures from regulators and other social actors are not fierce.

However, although Institutional Rational Choice provides a fresh conceptual approach to examine the various theoretical positions in explaining the diffusion of international HRM practices, it cannot claim to be a formal or "authentic" theory, in the narrow/strict sense of the word. It merely provides a "high-level" theoretical lens to investigate patterns and motives of practice adoption. It also lacks the precision of other attempts to provide an integrative framework, such as Edwards et al.'s (2007: 201) political economy approach, which aims to link "interrelationships between markets and institutions on the one hand and the material interests of actors on the other". Empirical studies on the diffusion of HRM practices, particularly those with a multi-level design at the national and/or sectoral and firm levels, are needed to ascertain the usefulness and explanatory power of the proposed IRC framework.

\section{References}

Abrahamson, E. (1991). Management fads and fashions: the diffusion and rejection of innovations. Academy of Management Review, 16 (3): 586 - 612.

Allen, M. (2004). The varieties of capitalism paradigm: not enough variety?. Socio-Economic Review, 2: 87 108. http://dx.doi.org/10.1093/soceco/2.1.87

Almond, P., and Ferner, A. (eds). (2006). American Multinationals in Europe: Managing Employment Relations 
across National Borders. Oxford: Oxford University Press.

Amable, B. (2000). Institutional complementarity and diversity of social systems of innovation and production. Review of International Political Economy, 7 (4): 645 - 687. http://dx.doi.org/10.1080/096922900750034572

Arias, M. (1993). MNCs, organizational models, and local firms in developing countries: the case of the pharmaceutical industry in Ecuador. paper presented at the 11th EGOS Colloquium, 6 - 8 July, Paris.

Atkinson, J. (1984). Manpower strategies for flexible organizations. Personnel Management, 16 (8): 28 - 31.

Barney, J. (1991). Firm resource and sustainable competitive advantage. Journal of Management, 17 (1): 99 120. http://dx.doi.org/10.1177/014920639101700108

Barreto, I., and Baden-Fuller, C. (2006). To conform or to perform? Mimetic behaviour, legitimacy-based groups and performance consequences. Journal of Management Studies, $43 \quad$ (7): 1559 - 1581. http://dx.doi.org/10.1111/j.1467-6486.2006.00620.x

Barry, M., and Nienheieser, W. (2010). Coordinated market economy/liberal employment relations: low cost competition in the German avaiation industry. International Journal of Human Resource Management, 21 (2/3): 214 - 229. http://dx.doi.org/10.1080/09585190903509522

Becker, B., and Gerhart, B. (1996). The impact of human resource management on organizational performance: progress and prospects. Academy of Management Journal, 39 (4): 779 - 801. http://dx.doi.org/10.2307/256712

Berglund, J., and Werr, A. (2000). The invincible character of management consulting rhetoric: how one blends incommensurates while keeping them apart. Organization, $7 \quad$ (4): $633 \quad$ - 655 . http://dx.doi.org/10.1177/135050840074008

Bjorkman, I. (2002). The diffusion of human resource management practices among Chinese firms: the role of Western multinational corporations. Asia Pacific Business Review 9 (2): $43 \quad$ - 60. http://dx.doi.org/10.1080/713999183

Boxall, P., and Purcell, J. (2000). Strategic human resource management: where have we come from and where should we be going? International Journal of Management Reviews, 2 (2): 183 - 203. http://dx.doi.org/10.1111/1468-2370.00037

Boxall, P., and Purcell, J. (2003). Strategy and Human Resource Management. Basingstoke: Palgrave Macmillan.

Boyer, R. (2000). Is finance led growth regime a viable alternative to Fordism? A preliminary analysis. Economy and Society, (29): 111 - 145. http://dx.doi.org/10.1080/030851400360587

Campbell, J. (2004). Institutional Change and Globalization. Princeton: Princeton University Press.

Casper, S., Lehrer, M., and Soskice, D. (1999). Can high-technology industries prosper in Germany? Institutional frameworks and the evolution of the German software biotechnology industries. Industry and Innovation, 6 (1): 5 - 25. http://dx.doi.org/10.1080/13662719900000002

Chanda, N. (2003). A Review of Globalinc, Yale Global Online. [Online] Available: http://yaleglobal.yale.edu/about/globalinc.jsp

Chen, S., Lawler, J., and Bae, J. (2005). Convergence in human resource systems: a comparison of locally owned and MNC subsidiaries in Taiwan. Human Resource Management, 44 (3): 237 - 256. http://dx.doi.org/10.1002/hrm.20069

Chow, I. (2004). The impact of institutional context on human resource management in three Chinese societies. Employee Relations, 26 (6): 626 - 642. http://dx.doi.org/10.1108/01425450410562218

Chung, H. (2007). Do countries matter? Explaining the variation in the rise of numerical flexibility arrangements across European companies using a multi-level model. Flexicurity Research Team, Tilburg University MPRA Paper Non. 5449, [Online] Available: http://mpra.ub.uni-muenchen.de/5449/1/MPRA_5449.pdf.

Cooke, F. (2005). HRM, Work and Employment in China. London: Routledge.

Crouch, C. (2005). Capitalist Diversity and Change. New York: Oxford University Press. http://dx.doi.org/10.1093/acprof:oso/9780199286652.001.0001

Dalton, N., and Benson, J. (2002). Innovation and change in Japanese human resource management. Asia Pacific Journal of Human Resources, 40 (3): 345 - 362. http://dx.doi.org/10.1177/1038411102040003257

Deeg, R., and Jackson, G. (2007). Towards a more dynamic theory of capitalist variety. Socio-Economic Review, (5): $149-179$.

DiMaggio, P., and Powell, W. (1983). The iron cage revisited: institutional isomorphism and collective 
rationality in organizational fields. American Sociological Review, $48: \quad 147 \quad-\quad 160$. http://dx.doi.org/10.2307/2095101

Djelic, M., and Quack, S. (2003). Conclusion: Globalization as a double process of institutional change and institutional building", in M. Djelic and S. Quack (eds) Globalization and Institutions: Redefining the Rules of the Economic Game. Cheltenham: Edward Elgar, pp $302-333$.

Ebbinghaus, B., and Visser, J. (1999). When institutions matter: union growth and decline in Western Europe. European Sociological Review, 15 (2): 135 - 158.

Edwards, T., Colling, T., and Ferner, A. (2007). Conceptual approaches to the transfer of employment practices in multinational companies: an integrated approach. Human Resource Management Journal, 17 (3): 201 - 217. http://dx.doi.org/10.1111/j.1748-8583.2007.00042.x

Farndale, E., Brewster, C., and Poutsma, E. (2008). Coordinated vs. liberal market HRM: the impact of institutionalization on multinational firms. International Journal of Human Resource Management, 19 (11): 2004 - 2023. http://dx.doi.org/10.1080/09585190802404247

Ferner, A., and Quintanilla, J. (1998). Multinationals, national business systems and HRM: the enduring influence of national identity or a process of 'Anglo-Saxonisation'. International Journal of Human Resource Management, 9 (4): 711 - 731.

Gamble, J. (2003). Transferring human resource practices from the United Kingdom to China: the limits and potential for convergence. International Journal of Human Resource Management, 14 (3): 369 - 387. http://dx.doi.org/10.1080/0958519022000031807

Gooderham, P., and Nordhaug, O. (1997). Flexibility in Norwegian and UK firms: competitive pressure and institutional embeddedness. Employee Relations, $19 \quad$ (6): 568 - 580. http://dx.doi.org/10.1108/01425459710367916

Gooderham, P., Nordhaug, O., and Ringdal, K. (1999). Institutional and rational determinants of organizational practices: human resource management in European firms. Administrative Science Quarterly, 44 (3): 507 - 532. http://dx.doi.org/10.2307/2666960

Guest, D. (1987). Human resource management and industrial relations. Journal of Management Studies, 24 (5): 505 - 521. http://dx.doi.org/10.1111/j.1467-6486.1987.tb00460.x

Guest, D., Michie, J., Conway, N., and Sheehan, M. (2003). Human resource management and corporate performance in the UK. British Journal of Industrial Relations, 41: 291 - 314. http://dx.doi.org/10.1111/1467-8543.00273

Haake, S. (2002). National business systems and industry-specific competitiveness. Organization Studies, 23 (5): 711 - 736. http://dx.doi.org/10.1177/0170840602235002

Hall, P., and Soskice, D. (eds) (2001). Varieties of Capitalism: The Institutional Foundations of Comparative Advantage. Oxford: Oxford University Press.

Harris, R. (2008). Black Robes, White Coats: The Puzzle of Judicial Policymaking and Scientific Evidence. New Jersey: Rutgers University Press.

Harzing, A., and Sorge, A. (2003). The relative impact of country-of-origin and universal contingencies on internationalization strategies and corporate control in multinational enterprises: World-wide and European perspectives. Organisation Studies, 24 (2): 187 - 214. http://dx.doi.org/10.1177/0170840603024002343

Heck, R. (2004). Studying Educational and Social Policy: Theoretical Concepts and Research Methods. Mahwah, NJ: Lawrence Erlbaum Associates.

Heery, E., and Noon, M. (2001). A Dictionary of Human Resource Management. Oxford: Oxford University Press.

Henisz, W., Zelner, B., and Guillen, M. (2004). International coercion, emulation and policy diffusion: market-oriented infrastructure reforms, 1977-1999. [Online] Available: http://ssrn.com/abstract $=557140$

Hollingsworth, J. (1997). Continuities and changes in social systems of production: the cases of Japan, Germany, and the United States, in J. Hollingsworth and R. Boyer (eds) Contemporary Capitalism: the Embeddedness of Institutions. Cambridge and New York: Cambridge University Press, pp. 265 - 310.

Hollingsworth, J., and Boyer, R. (1997). Co-ordination of economic actors and social systems of production", in J. Hollingsworth and R. Boyer (eds) Contemporary Capitalism: The Embeddedness of Institutions. Cambridge: Cambridge University Press, pp 1 - 47.

Hollingsworth, J., Schmitter, P., and Streeck, W. (1994). Governing Capitalist Economies. Oxford: Oxford 
University Press.

Howorth, C., Mueller, F., and Harvey, C. (2002). The diffusion of an organizational innovation: adopting patient-focused care in an NHS hospital trust. Competition and Change, 6 (2): 213 - 232. http://dx.doi.org/10.1080/10245290213674

Hunter, L. (1995). How will competition change human resource management in retail banking? A strategic perspective. Wharton Financial Institutions Centre Working Paper Series - Number 95-04. University of Pennsylvania: The Wharton School.

Huselid, M. (1995). The impact of human resource management practices on turnover, productivity, and corporate financial performance. Academy of Management Journal, 38 (3): 635 - 672. http://dx.doi.org/10.2307/256741

Ichniowski, C., Kochan, T., Levine, D., Olson, C., and Strauss, G. (2000). "What works at work: overview and assessment", in C. Ichniowski, D. Levine, C. Olson and G. Strauss (eds) The American Workplace: Skills, Pay and Employee Involvement. New York and Melbourne: Cambridge University Press, pp 1 - 37. http://dx.doi.org/10.1017/CBO9780511620027.002

Ietto-Gillies, G. (2002). Transnational Corporations: Fragmentation amidst Integration. London: Routledge.

Ingram, P., and Clay, K. (2000). The choice-within-constraints new institutionalism and implications for sociology. Annual Review of Sociology, 26: 525 - 546. http://dx.doi.org/10.1146/annurev.soc.26.1.525

John, P. (1998). Analyzing Public Policy. London and New York: Continuum.

Kamoche, K. (1996). Strategic human resource management within a resource-capability view of the firm. Journal of Management Studies, 33 (2): 213 - 233. http://dx.doi.org/10.1111/j.1467-6486.1996.tb00158.x

Kamoche, K. (2000). Sociological Paradigms and Human Resources: An African Context. Aldershot: Ashgate.

Katz, H., and Darbishire, O. (2000). Converging Divergences: Worldwide Changes in Employment Systems. Ithaca, NY: Cornell University Press.

Keltner, B., and Finegold, D. (1996). Adding value in banking: human resource innovations for service firms. Sloan Management Review, 38 (1): 57 - 68.

Khan, A., and Ackers, P. (2004). Neo-pluralism as a theoretical framework for understanding HRM in sub-Saharan Africa. International Journal of Human Resource Management, 15 (7): 1330 - 1353. http://dx.doi.org/10.1080/0958519042000238482

Kostova, T., and Roth, K. (2002). Adoption of an organizational practice by subsidiaries of multinational corporations: institutional and relational effects. Academy of Management Journal, 45(1): 215 - 233. http://dx.doi.org/10.2307/3069293

Kuruvilla, S., and Erickson, C. (2002). Change and transformation in Asian industrial relations. Industrial Relations, 41 (2): 171 - 227. http://dx.doi.org/10.1111/1468-232X.00243

Lane, C. (1989). Management and Labor in Europe: The Industrial Enterprise in Germany, Britain and France. Aldershot: Edward Elgar.

Lane, C. (2000). Understanding the globalization strategies of German and British multinational companies: Is a societal effects approach still useful?, in M. Maurice and A. Sorge (eds) Embedding Organizations. Amsterdam: John Benjamins, pp 189 - 208.

Lawler, J., Zaidi, M., and Atmiyanandana, V. (1989). "Human resource strategies in Southeast Asia: the case of Thailand" in A. Nedd, C. Ferris, and K. Rowland (eds) Research in Personnel and Human Resources Management (Supplement 1). Greenwich, CN: JAI Press.

Lazonick, W. (1993). Industry clusters versus global webs: organizational capabilities in the American economy. Industrial and Corporate Change, 2 (1): 1 - 24. http://dx.doi.org/10.1093/icc/2.1.1

Leseure, M., Bauer, J., Birdi, K., Neely, A., and Denyer, D. (2004). The adoption of promising practices: a systematic review of the evidence. International Journal of Management Reviews, 5/6 (3/4): 169 - 190. http://dx.doi.org/10.1111/j.1460-8545.2004.00102.x

Li, J., Yang, J., and Yue, D. (2007). Identity, community and audience: how wholly owned foreign subsidiaries gain legitimacy in China. Academy of Management Journal, 50 (1): $175 \quad-190$. http://dx.doi.org/10.5465/AMJ.2007.24162209

Lincoln, J., and Nakata, Y. (1997). The transformation of the Japanese employment system. Work and Occupations, 24 (1): 33 - 55. http://dx.doi.org/10.1177/0730888497024001004 
Looise, J., Riemsdijk, M., and Lange, F. (1998). Company labour flexibility strategies in the Netherlands: an institutional perspective. Employee Relations, 20 (5): 461 - 482. http://dx.doi.org/10.1108/01425459810238747

Mamman, A. (2002). The adoption and modification of management ideas in organizations: towards an analytical framework. Strategic Change, 11 (7): 379 - 389. http://dx.doi.org/10.1002/jsc.608

Marchington, M. (1990). Analyzing the links between product markets and the management of employee relations. Journal of Management Studies, $\begin{array}{llllll} & 27 & \text { (2): } & 111 & \text { - } & 132 .\end{array}$ http://dx.doi.org/10.1111/j.1467-6486.1990.tb00756.x

Marchington, M., and Grugulis, I. (2000). Best practice human resource management: perfect opportunity or dangerous illusion?. International Journal of Human Resource Management, 11 (6): 1104 - 1124. http://dx.doi.org/10.1080/09585190050177184

Maurice, M., Sorge, A., and Warner, M. (1980). Societal differences in organising manufacturing units: a comparison of France, West Germany, and Great Britain. Organization Studies, 1 (1): 59 - 86. http://dx.doi.org/10.1177/017084068000100105

McCann, L., and Schwartz, G. (2006). Terms and conditions apply: management restructuring and the global integration of post-socialist societies. International Journal of Human Resource Management, 17 (8): 1339 1352. http://dx.doi.org/10.1080/09585190600804713

McKinley, W., Sanchez, C., and Schick, A. (1995). Organizational downsizing: constraining, cloning, learning. Academy of Management Executive, 9 (3): 32 - 42. http://dx.doi.org/10.5465/AME.1995.9509210276

McSweeney, B., Smith, C., and Fitzgerald, R. (2008). Remaking management: neither global nor national, in C. Smith, B. McSweeney and R. Fitzgerald (eds.) Re-making Management: between Local and Global. Cambridge: Cambridge University Press, pp.1-16. http://dx.doi.org/10.1017/CBO9780511753800.001

Morishima. (2003). Changes in Japanese human resource management: a demand-side. Japan Labour Bulletin 42 (9): September. [Online] Available: http://www.jil.go.jp/bulletin/year/2003/vol42-09.pdf\#special

Morris, J., Hassard, J., and McCann, L. (2006). New organizational forms, human resource management and structural convergence? A Study of Japanese Organizations. Organization Studies, 27 (10): 1485-1511. http://dx.doi.org/10.1177/0170840606067513

Mueller, F. (1994). Societal effect, organizational effect and globalization. Organization Studies, 15 (3): 407 428.

Muller-Camen, M., Croucher, R., Flynn, M., and Schroder, H. (2011). National institutions and employers' age management practices in Britain and Germany: 'path depedence' and option creation. Human Relations (forthcoming). http://dx.doi.org/10.1177/017084069401500305

Oliver, N., and Wilkinson, B. (1992). The Japanization of British Industry. Cambridge: Blackwell Publishers.

Orru, M., Biggart, N., and Hamilton, G. (1991). Organizational isomorphism in East Asia”, in P. DiMaggio and W. Powell (eds) The New Institutionalism in Organizational Analysis. Chicago: University of Chicago Press, pp $361-389$.

Ostrom, E. (1999). "Institutional rational choice: an assessment of the institutional analysis and development framework", in P. Sabatier (ed) Theories of the Policy Process. Boulder, CO: Westview Press, pp 35 - 71.

Oxenbridge, S., Wallace, J., White, L., Tierman, S., and Lansbury, R. (2010). A comparative analysis of restructuring employment relationships in Qantas and Aer Lingus: different routes, similar destinations. International Journal of Human Resource Management, $\quad(2 / 3)$ : 180 - 196. http://dx.doi.org/10.1080/09585190903509472

Parry, E., Dickmann, M., and Morley, M. (2008). North American MNCs and their HR policies in liberal and coordinated market economies. International Journal of Human Resource Management, 19 (11): 2024 - 2040. http://dx.doi.org/10.1080/09585190802404262

Perlmutter, H. (1969). The tortuous evolution of the multinational corporation. Columbia Journal of World Business, 4 (1): 9 - 18.

Pfeffer, J. (1994). Competitive Advantage through People. Boston, MA: Harvard Business School Press.

Pfeffer, J. (1998). The Human Equation: Building Profits by Putting People First. Boston, MA: Harvard Business School Press.

Pfeffer, J., and Salancik, G. (1978). The External Control of Organizations: A Resource Dependent Perspective. New York: Harper and Row. 
Quack, S., O'Reilly, J., and Hildebrandt, S. (1995). Structuring change: training and recruitment in retail banking in Germany, Britain and France. International Journal of Human Resource Management, 6 (4): 759 - 794. http://dx.doi.org/10.1080/09585199500000047

Ramaswamy, E., and Schiphorst, F. (2000). Human resource management, trade unions and empowerment: two cases from India. International Journal of Human Resource Management, 11 (4): 664 - 680. http://dx.doi.org/10.1080/09585190050075051

Rosenzweig, P., and Nohria, N. (1994). Influences on human resource practices in multinational corporations. Journal of International Business Studies, 25 (2): 229 - 251. http://dx.doi.org/10.1057/palgrave.jibs.8490199

Rowley, C., and Bae, J. (2002). Globalization and transformation of human resource management in South Korea. International Journal of Human Resource Management, 13 (3): 522 - 549. http://dx.doi.org/10.1080/09585190110111512

Rubery, J., and Grimshaw, D. (2003). The Organization of Employment: An International Perspective. Basingstoke: Palgrave Macmillan.

Rubery, J., and Wilkinson, F. (1994). Introduction, in J. Rubery and F. Wilkinson (eds) Employer Strategy and the Labour Market. Oxford: Oxford University Press.

Schief, S. (2010). Does location matter? An empirical investigation of flexibility patterns in foreign and domestic companies in five European countries. International Journal of Human Resource Management, 21 (1): 1 - 16. http://dx.doi.org/10.1080/09585190903466830

Schmitt, M., and Sadowski, D. (2003). A cost-minimization approach to the international transfer of HRM/IR practices: Anglo-Saxon multinationals in the Federal Republic of Germany. International Journal of Human Resource Management, 14 (3): 409 - 430. http://dx.doi.org/10.1080/0958519022000031825

Schuler, R., and Jackson, S. (1987). Linking competitive strategy with human resource management practices. Academy of Management Executive, 3: 207 - 219. http://dx.doi.org/10.5465/AME.1987.4275740

Scott, R. (1995). Institutions and Organizations. Thousand Oaks, CA: Sage.

Scott, R. (2001). Institutions and Organizations. (2nd ed.). Thousand Oaks, CA: Sage.

Sett, P. (2004). Human resource management and firm level restructuring: the South Asian drama. Research and Practice in Human Resource Management, 12(1): 1 -33.

Snell, S., Youndt, M., and Wright, P. (1996). Establishing a framework for research in strategic human resource management: Merging resource theory and organizational learning. in J. Shaw, P. Kirkbride and K. Rowland (eds), Research in Personnel And Human Resource Management, 14: 61 - 90.

Som, A. (2007). What drives adoption of SHRM practices in Indian organizations. International Journal of Human Resource Management, 18 (5): 808 - 828. http://dx.doi.org/10.1080/09585190701248695

Sorge, A. (1983). Review of culture's consequences: international differences in work-related values. Administrative Science Quarterly, 28 (December): 625 - 629. http://dx.doi.org/10.2307/2393017

Sorge, A. (2005). The Global and the Local: Understanding the Dialectics of Business. Oxford: Oxford University Press.

Streeck, W. (1997). "German capitalism: Does it exist? Can it survive?", in C. Crouch and W. Streek (eds) Political Economy of Modern Capitalism: Mapping Convergence and Diversity. London: Sage.

Streeck, W., and Thelen, K. (2005). (eds) Beyond Continuity: Institutional Change in Advanced Political Economies. Oxford: Oxford University Press.

Sturdy, A. (2004). The adoption of management ideas and practices: theoretical perspectives and possibilities. Management Learning, 35 (2): 155 - 179. http://dx.doi.org/10.1177/1350507604043023

Subramony, M. (2006). Why organizations adopt some human resource management practices and reject others: an exploration of rationales. Human Resource Management, 45 (2): 195 - 210. http://dx.doi.org/10.1002/hrm.20104

Susskind, L., Jain, R., and Martyniuk, A. (2001). Better Environmental Policy Studies: How to Design and Conduct More Effective Analyses. Island Press: Washington.

Swart, J., Kinnie, N., and Purcell, J. (2002). HR systems in growing knowledge-intensive firms: the impact of client relationships", Paper to the HRM and Performance Conference, Bath University, April.

Taylor, S., Beechler, S., and Napier, N. (1996). Toward an integrative model of strategic international human resource management. Academy of Management Review, 21 (4): 959 - 985. 
Tempel, A. (2001). The Cross-National Transfer of Human Resource Management Practices in German and British Multinational Companies. München and Mering: Rainer Hampp Verlag.

Tempel, A., and Walgenbach, P. (2007). Global standardisation of organizational forms and management practices? What new institutionalism and the business-systems approach can learn from each other. Journal of Management Studies, 44 (1): 1 - 24. http://dx.doi.org/10.1111/j.1467-6486.2006.00644.x

Thelen, K. (2004). How Institutions Evolve: The Political Economy of Skills in Germany, Britain, Japan and the United States. Cambridge: Cambridge University Press. http://dx.doi.org/10.1017/CBO9780511790997

Venkata Ratnam, C. (1998). Multinational companies in India. International Journal of Human Resource Management, 9 (4): 567 - 589. http://dx.doi.org/10.1080/095851998340900

Vitols, S. (2004). Negotiated shareholder value: the German version of an Anglo-American practice. Competition and Change, 8: 1 - 18. http://dx.doi.org/10.1080/1024529042000304400

Warner, M. (2000). "Society, organization and work in China", in M. Maurice and A. Sorge (eds) Embedding Organizations. Amsterdam: John Benjamins, pp 257 - 272.

Warner, M. (2004). Human resource management in China revisited: introduction. International Journal of Human Resource Management, 15 (4-5): 617 - 634. http://dx.doi.org/10.1080/0958519042000192861

Weinstein, M., and Kochan, T. (1995). "The limits of diffusion: recent developments in industrial relations and human resource practices in the United States", in R. Locke, T. Kochan and M. Piore (eds) Employment Relations in a Changing World Economy, Cambridge, MA: Harvard Business School Press.

Westney, D. (1993). "Institutionalisation theory and the multinational corporation", in S. Ghoshal and D. Westney (eds) Organization Theory and the Multinational Corporation. New York: St. Martin's Press, pp 53 76.

Whitley, R. (1999). Divergent Capitalisms: The Social Structuring and Change of Business Systems. Oxford: Oxford University Press.

Whittington, R. (1992). Putting giddens into action: social systems and managerial agency. Journal of Management Studies, 29 (4): 693 - 712. http://dx.doi.org/10.1111/j.1467-6486.1992.tb00685.x

Willman, P., Bryson, A., and Gomez, R. (2006). The sound of silence: which employers choose no employee voice and why? Socio-Economic Review, 4: 283 - 299. http://dx.doi.org/10.1093/ser/mwl012

Wood, G., and Brewster, C. (eds) (2007). Industrial Relations in Africa. London: Palgrave Macmillan.

Wood, S., and de Menezes, L. (1998). High commitment management in the UK: evidence from the Workplace Industrial Relations Survey and Employers Manpower and Skills Survey. Human Relations, 51 (4): 485 - 515. http://dx.doi.org/10.1023/A:1016941914876

Wright, C., and Kitay, J. (2004). Spreading the word: gurus, consultants and the diffusion of the employee relations paradigm in Australia. Management Learning, $35 \quad$ (3): 271 - 286. http://dx.doi.org/10.1177/1350507604045606

Wright, P., McMahan, G., and McWilliams, A. (1994). Human resources and sustained competitive advantage: a resource-based perspective. International Journal of Human Resource Management, 5 (2): 301 - 326. http://dx.doi.org/10.1080/09585199400000020 